\title{
プロポリスのキサンチンオキシダーゼ活性阻害作用及び血漿尿酸値低下作用
}

\author{
吉積一 真, ${ }^{*}, a$ 西岡 信 雄, ${ }^{b}$ 辻 智子 $a$
}

\section{The Xanthine Oxidase Inhibitory Activity and Hypouricemia Effect of the Propolis in Rats}

\author{
Kazuma YoshizUMI, ${ }^{*, a}$ Nobuo NiSHIOKA, ${ }^{b}$ and Tomoko TsUJ ${ }^{a}$ \\ Fancl Corporation Central Research Laboratory, ${ }^{a}$ 12-13 Kamishinano, Totsuka-ku, Yokohama \\ 244-0806, Japan and Morikawa Kenkodo Co., Ltd., ${ }^{b} 2170$ Taguchi, Kousa-machi, \\ Kamimashiki-gun, Kumamoto 861-4616, Japan
}

(Received December 13, 2004; Accepted December 18, 2004)

\begin{abstract}
The xanthine oxidase (XOD) inhibitory activity of propolis from China and Brazil was measured. The propolis from both place were seen to have XOD inhibitory activity. However, a stronger tendency was shown in the propolis from China. The compounds in each the propolis were measured quantitatively. A great deal of chrysin, galangin, and caffeic acid phenetyl ester were found in the propolis from China, an abundance of $p$-coumaric acid and artepillin C in the propolis from Brazil. Therefore it was revealed that the propolis compounds are very different depending on their place of origin. The XOD inhibitory activity of these five compounds was measured. Caffeic acid phenetyl ester had the strongest activity, with chrysin and galangin next; $p$-coumaric acid and artepillin $C$ showed weak XOD inhibitory activity. We evaluated the hypouricemic effect of propolis from China on hyperuricemia induced by the uricase inhibitor, oxonic acid $(500 \mathrm{mg} / \mathrm{kg}$ p.o., $1 \mathrm{~h}$ before the test drugs), and measured plasma uric acid values in rats. Oral propolis had a hypouricemic effect $2 \mathrm{~h}$ after its administration to oxonate-pretreated rats. These results suggested that a continuous intake of propolis may be effective for the prevention and the treatment of gout and hyperuricemia.
\end{abstract}

Key words_ propolis; xanthine oxidase inhibitor; gout and hyperuricemia; uric acid; oxonic acid

\section{緒言}

わが国において，痛風及びその予備群である高尿 酸血症は食生活の欧米化などに伴い，その患者数は 年々増加している。痛風, 高尿酸血症の多くは遺伝 的素因に過食, 肥満, 常習飲酒, ストレスなどの生 活環境の異常が重なって発症する。わが国の痛風患 者数は 30-50万人存在し, そのほとんどが男性で ある. 高尿酸血症患者はさらに多数であり, 痛風及 び高尿酸血症患者を合わせると，450-500万人に も上ると推定されている。1）このような痛風，高尿 酸血症では，同様の生活環境の異常が発症に関与す る腎障害, 高血圧, 高脂血症や耐糖能異常などの生 活習慣病を複合的に合併している場合が多い. ${ }^{2,3}$

痛風, 高尿酸血症は, 血漿での尿酸が増加するこ とにより引き起こされる病気であるが，この血漿尿

$a$ 株式会社ファンケル中央研究所, $b$ 森川健康堂株式会 社

e-mail: kayoshizu@ fancl.co.jp
酸值を正常值内にコントロールすることが, これら の病気に対する予防，治療の基本である。一般に， 痛風あるいは高尿酸血症は体内で尿酸が過剰に産生 される産生過剰型, 腎臓機能の低下により尿酸の排 泄能力が低下している排泄低下型, 両者を併せ持つ た混合型に分けることができるが, どの型の痛風, 高尿酸血症患者も，血漿尿酸值を正常值にまで低下 させることにより, 急性発作の減少, 慢性化への停 止, 腎・血管系への合併症の予防及び悪化を防ぐこ とができる，そこで，産生過唾型の痛風，高尿酸血 症患者に対しては尿酸生成抑制薬であるアロプリ ノール4)が, 排泄低下型, 混合型の痛風, 高尿酸血 症患者に対しては尿酸排泄促進薬であるプロベネシ ド，ベンズブロマロンな゙ごが臨床の場で使用され ているが，蕁麻疹や皮疹，肝機能障害などの副作用 を伴う場合が多い. ${ }^{4,5)}$

プロポリスは，ミツバチが周辺の植物の芽や浸出 物を集めて作った樹脂状物質であり，主な成分は， 樹脂, ろう質, 花粉, その他ミネラル類などであ 
る。このプロポリス中には，桂皮酸や $p$-クマール 酸などのフェノール酸類，フラボノイドなど多くの ポリフェノールが含まれているため, 生体内におい て種々の薬理学的効果が期待できる.

プロポリスは古くから東ヨーロッパを中心とした 世界中の多くの地方で民間伝承薬として用いられ， 抗癌作用, ${ }^{6)}$ 抗炎症作用, ${ }^{7)}$ 抗酸化作用, ${ }^{8)}$ 免疫賦活 作用, 9) 抗ウイルス作用, ${ }^{10)}$ 肝保護作用 ${ }^{11)}$ など数多 くの薬理学的作用や治療効果が報告されており，ド イツにおいては医薬品としても認可されている.

近年，プロポリスの成分分析研究が進み，ブラシ

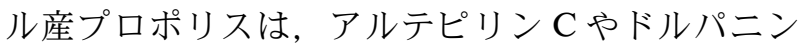
などの桂皮酸誘導体が主成分であり，ブラジル産以 外の中国産，オーストラリア産，ヨーロッパ産，ウ ルグアイ産などのプロポリスは, クリシンやピノセ ンブリン，ガランギンなどのフラボノイドが主成分 であることが明らかとなっている. ${ }^{12)}$ また，熊澤ら はブラジル産とそれ以外の産地のプロポリスでは, 抗酸化作用が大きく異なることを報告している. ${ }^{13)}$ このようにプロポリスは，産地により含有する成分 や薬理学的作用が大きく異なると考えられている.

また，フラボノイド14-16)やクマリン及びその誘 導体, ${ }^{17)}$ カフェー酸及びその誘導体18)などにキサン チンオキシダーゼ（以下，XOD とする）活性の阻 害作用を有することが報告されていることから，プ ロポリスが XOD 活性を阻害して血漿尿酸值を低下 させることにより, 痛風や高尿酸血症の予防や治療 に有効であることが示唆される。

そこで今回，プロポリス中の代表的な成分として クリシン，ガランギン，アルテピリン $\mathrm{C}, p$ - クマー ル酸及びカフェー酸フェネチルエステル（Fig. 2) を選択し，産地の異なるプロポリス，すなわち，中 国産及びブラジル産プロポリス中の含有量を測定す るとともに，XOD 活性阻害作用を比較し，さらに オキソニン酸誘発高尿酸血症モデル動物を作製し, プロポリスの血漿尿酸值低下作用についても検討を 行った.

\section{試薬及び試験方法}

1. 試薬クリシン，ガランギン，アルテピリ ン $\mathrm{C}, p$ - クマール酸及びキサンチンは，和光純薬工 業侏（大阪）より購入したものを，カフェー酸フェ ネチルエステル，アロプリノール，プロベネシドは
シグマ (St. Louis, M.O.) より購入したものを使 用した。また，オキソニン酸は，アルドリッチ (Milwaukee, W.I.) より購入したオキソニン酸カリ ウム塩を, XOD（Butter milk 由来）はオリエンタ ル酵母工業侏(大阪)より購入したものを使用した.

2. 試験物質の抽出 ブラジル及び中国におい て入手したプロポリス原塊 $1 \mathrm{~kg}$ を粉砕後, 10 倍量 の $80 \%$ 含水エタノールで浸漬抽出し（常温，3 日 間)，万過後，減圧濃縮乾固することにより， $80 \%$ 含水エ夕ノール抽出物をそれぞれ $460 \mathrm{~g}, 375 \mathrm{~g}$ を得 た.

3. 各成分の定量 Figure 2 中に示した 5 つの 成分の定量は，各標準品を用いて検量線を作成した のち，被験物質を HPLC（LC-2010A，㧣島津製作 所，京都）を用いて定量を行った。

すなわち，検体 $2 \mathrm{ml}$ に適当量のメタノールを加 え，超音波抽出を行う。その後，メタノールを加え て $50 \mathrm{ml}$ に定容した。これを直接，あるいは適宜希 釈して, ミリポアろ過したものを HPLC 分析に供 した.

\section{HPLC 分析条件}

(1) アルテピリン C

カラム : STR ODS-II $\phi 4.6 \mathrm{~mm} \times 15 \mathrm{~cm}$ (信和化工 秼，京都）

移動相：A 液 $5 \%$ ギ酸， B 液 メタノール

$\mathrm{A}: \mathrm{B}=70: 30(\mathrm{v} / \mathrm{v}) \longrightarrow 0: 100(\mathrm{v} / \mathrm{v}) 35$ 分間の リニアグラジエント

測定波長 : $280 \mathrm{~nm}$, 流速 : $1.0 \mathrm{ml} / \mathrm{min}$, カラム温 度: $40^{\circ} \mathrm{C}$

(2) $p$-クマール酸

カラム : YMC-Pack ODS-A A-312 $\phi 6.0 \mathrm{~mm} \times 15 \mathrm{~cm}$ (陎ワイエムシィ，京都）

移動相 : $2.5 \%$ 䣷酸 : メタノール : アセトニトリル $=50: 8: 5(\mathrm{v} / \mathrm{v} / \mathrm{v})$

測定波長： $320 \mathrm{~nm}$, 流速 : $1.0 \mathrm{ml} / \mathrm{min}$, カラム温 度: $40^{\circ} \mathrm{C}$

(3) クリシン及びガランギン

カラム : YMC-Pack ODS-A A-312 $66.0 \mathrm{~mm} \times 15 \mathrm{~cm}$ （侏ワイエムシィ，京都）

移動相：2.5\%酢酸：メタノール：アセトニトリル $=25: 10: 10(\mathrm{v} / \mathrm{v} / \mathrm{v})$

測定波長 : $360 \mathrm{~nm}$, 流速 : $1.0 \mathrm{ml} / \mathrm{min}$ ，カラム温 度 : $40^{\circ} \mathrm{C}$ 
(4) カフェー酸フェネチルエステル

カラム : STR ODS-II $\phi 4.6 \mathrm{~mm} \times 15 \mathrm{~cm}$ （信和化工 (株，京都)

移動相：A 液 2.5\%酢酸， B 液 アセトニトリル,

$\mathrm{C}$ 液 メ夕ノール

0 分 $\rightarrow 40$ 分 : A : B : C =75:25:0(v/v/v)

40 分 $\rightarrow 50$ 分 : A : B : C = 50:30:20(v/v/v)

測定波長 : $330 \mathrm{~nm}$, 流速 : $1.0 \mathrm{ml} / \mathrm{min}$, カラム温 度 : $40^{\circ} \mathrm{C}$

4. キサンチンオキシダーゼ活性阻害作用の測定 XOD 活性阻害作用の測定は，Chang ら 14)及び Nagao ら ${ }^{15)}$ の方法を一部改変して，産生される尿酸の 量を HPLC により測定することにより求めた.

すなわち，12.5 mM リン酸カリウム緩衝液（pH 7.8）に溶解させた $50 \mu \mathrm{M}$ キサンチン緩衝液に，各 濃度に調製した試験試料 $10 \mu \mathrm{l}$ を加えて $37^{\circ} \mathrm{C} て ゙ 5$ 分間，プレインキュベーションした。 その後， XOD 緩衝液 $(0.1 \mathrm{mU})$ を加え， $37^{\circ} \mathrm{C}$ で 10 分間个 ンキュベーションしたのち， $3.2 \%$ 過塩素酸溶液を 加え反応を停止し, その後, $0.4 \mathrm{M}$ リン酸カリウム 緩衝液（pH 7.8）及びアセトニトリルを加えたあと に, 産生した尿酸の量を HPLC (検出器 : UV-970, ポンプ：PU-980, 日本分光(侏), 東京) にて測定し た.

測定条件は, カラム : Shim-Pack CLC-NH N $_{2}$ ( 6.0 $\mathrm{mm} \times 150 \mathrm{~cm}$ ，秼島津製作所，京都）を用い，移動 相 : アセトニトリル $/ 20 \mathrm{mM}$ リン酸二水素カリウム (3: $2 \mathrm{v} / \mathrm{v})$ 水溶液, 流速 $: 1.0 \mathrm{ml} / \mathrm{min}$, 温度 : 30 ${ }^{\circ} \mathrm{C}$, 検出波長： $290 \mathrm{~nm}$ であり，この条件では尿酸 のピーク面積は 6.2 分付近に検出された.

なお，阻害率（\%）は，試験試料を加えてない場 合に産生される尿酸量（ $\Delta_{\text {A-control }}$ ）に対する各濃度 に調製した試験試料を加えた場合に産生される尿酸 量 $\left(\Delta_{\mathrm{A}-\mathrm{test}}\right)$ の減少量で表した.

阻害率 $(\%)=\left(1-\Delta_{\mathrm{A} \text {-test }} / \Delta_{\mathrm{A}-\text { control }}\right) \times 100$

5. 動物, 飼料及び飼育動物は, 5 週齢の雄 性 SD 系ラット (日本チャールズリバー(株), 神奈川) を購入し，十分検疫訓化したあとに一般状態の観察 及び体重測定を行い，健康状態が良好な動物を選ん で 6 週齢で使用した。

ラットは温度： $22 \pm 3{ }^{\circ} \mathrm{C}$, 湿度 : $55 \pm 15 \%$ ，換 気：常時オールフレッシュ方式，照明：12 時間/日 (午前 6 時より午後 6 時), 照度 : 150-300 ルクス
に設定し，ステンレス製ブラケット飼育ゲージに 1 匹ずつ収容した。

飼料は，実験動物用粉末飼料及び固形飼料（飼育 /繁殖用）CE-2（日本クレア(株）東京）を，飲料水 は水道水を自動給水装置でいずれも自由摂取させた。

また，この実験計画及び実施に当たつては，総理 府公示第 6 号（昭和 55 年 3 月） “実験動物の飼養及 び保管等に関する基準”に準じて行った。

6. オキソニン酸誘発高尿酸血症ラットにおける 血漿尿酸值の測定本試験は，Osada ら ${ }^{19)}$ 及び Yonetani ら 20)の方法を一部改変して行った.

すなわち，ラットを血漿尿酸值と体重が各群で平 均化するようにして，1 群５匹で無処置群，高尿酸 血症群（以下，対照群とする)，アロプリノール 10 $\mathrm{mg} / \mathrm{kg}$ 投与群, プロベネシド $100 \mathrm{mg} / \mathrm{kg}$ 投与群, プロポリス $500 \mathrm{mg} / \mathrm{kg}$ 投与群の 5 群に分けた.

ラットは非絶食下で用いた。まず， $500 \mathrm{mg} / \mathrm{kg}$ の オキソニン酸 $0.5 \%$ カルボキシメチルセルロース (CMC) 水溶液を経口投与した. この 1 時間後に, 溶媒又は被験物質液を経口投与した。採血は，才キ ソニン酸投与 1 時間前, 溶媒又は被験物質液投与 1,2 及び 3 時間後に尾静脈から行い，血漿を調製し て尿酸の測定に供した。尿酸の測定に当たつては, 市販測定キット(ウリックアシッドーテストワコー： 和光純薬工業(怢)，大阪）を用いて測定した。

結果は，平均值士標準誤差で表した。高尿酸血症 モデルの確立の検討として, 無処置群と対照群の 2 群間において，無処置群を基準として各採血時点で $t$ - 検定を行った。被験物質の有効性を検討するた め，無処置群を除いた 4 群で無処置群を基準として 各採血時点で Dunnett の多重比較を行った. $p$ 值が 0.05 未満であったとき「有意である」と判定し, 有意差水準として 5\%，1％及び $0.1 \%$ を使用した。

\section{結果及び考察}

わが国において，痛風は食生活の欧米化などに伴 い，その患者数は年々増加してきた。痛風の予備軍 とも言える高尿酸血症患者はさらに多数であり，や はり痛風と同様に増加している。

高尿酸血症とは, 血漿中の尿酸濃度が一定以上に 上昇した状態であり，血漿尿酸の飽和度を越える状 態を指す。近年, この血漿尿酸值管理の対策とし て，生活習慣の中で重要な位置を占める食に注目 
し，食品の持つ生体調節機能を利用して血漿尿酸值 を低下させようとする試みが精力的になされてい る. ${ }^{21-23)}$

そこで，われわれは，オキソニン酸誘発高尿酸血 症ラットにおけるプロポリスの血漿尿酸值低下作用 について検討を行った.

まず，中国産及びブラジル産プロポリスの XOD 活性阻害作用について検討を行ったところ，Fig. 1 に示したように，両産地のプロポリスも濃度依存的 にXOD 活性を阻害したが，その阻害作用は中国産 の方が強い傾向を示した。

次に, プロポリスの産地により含有する成分が大 きく異なることが報告されている12)ことから，代表 的な成分である Fig. 2 に示したクリシン，ガラン ギン，アルテピリン $\mathrm{C}, p$ - クマール酸及びカフェー 酸フェネチルエステルの 5 成分について, 中国産及 びブラジル産プロポリス中の含有量の定量を行っ た。その結果，Table 1 に示したように，中国産に おいてはクリシンやガランギン及びカフェー酸フェ ネチルエステルが多く含まれており，一方，ブラジ ル産はアルテピリン $\mathrm{C}$ や $p$-クマール酸が多く含ま れていることが明らかとなり，産地により含有する
成分が大きく異なることが示された。

さらに，これら 5 成分とXOD 活性阻害作用との 関係を明らかにする目的で，5成分の XOD 活性阻 害作用について検討を行ったところ, Table 2 に示 したように, カフェー酸フェネチルエステルの阻害 作用が最も強く，ついでクリシン及びガランギンで あり，アルテピリン $\mathrm{C}$ や $p$-クマール酸は弱い阻害 作用であった。この結果は, 中国産がブラジル産よ りもXOD 活性阻害作用が強い傾向を示した結果と 一致しており，中国産でフラボノイドやカフェー酸 フェネチルエステルの含有量が大きいことが，阻害 作用の強さに一部起因していると考えられる。しか し，プロポリス中にはこれら 5 成分以外にも多くの 化合物が含有されていることから，さらに他の成分 についても単離を行い，阻害作用を測定するなど, 詳細な検討が必要であると考えられる.

ヒトにおいて，食事由来の核酸やプリン化合物 は，プリン代謝最終産物として尿酸の形で尿中に排 泄される。しかし，マウスやラットなどのげっ歯類 は，尿酸酸化酵素であるウリカーゼにより尿酸から さらにアラントインにまで代謝されて尿中に排泄さ れる. ${ }^{24)}$ そこでわれわれは，ウリカーゼ阻害薬であ

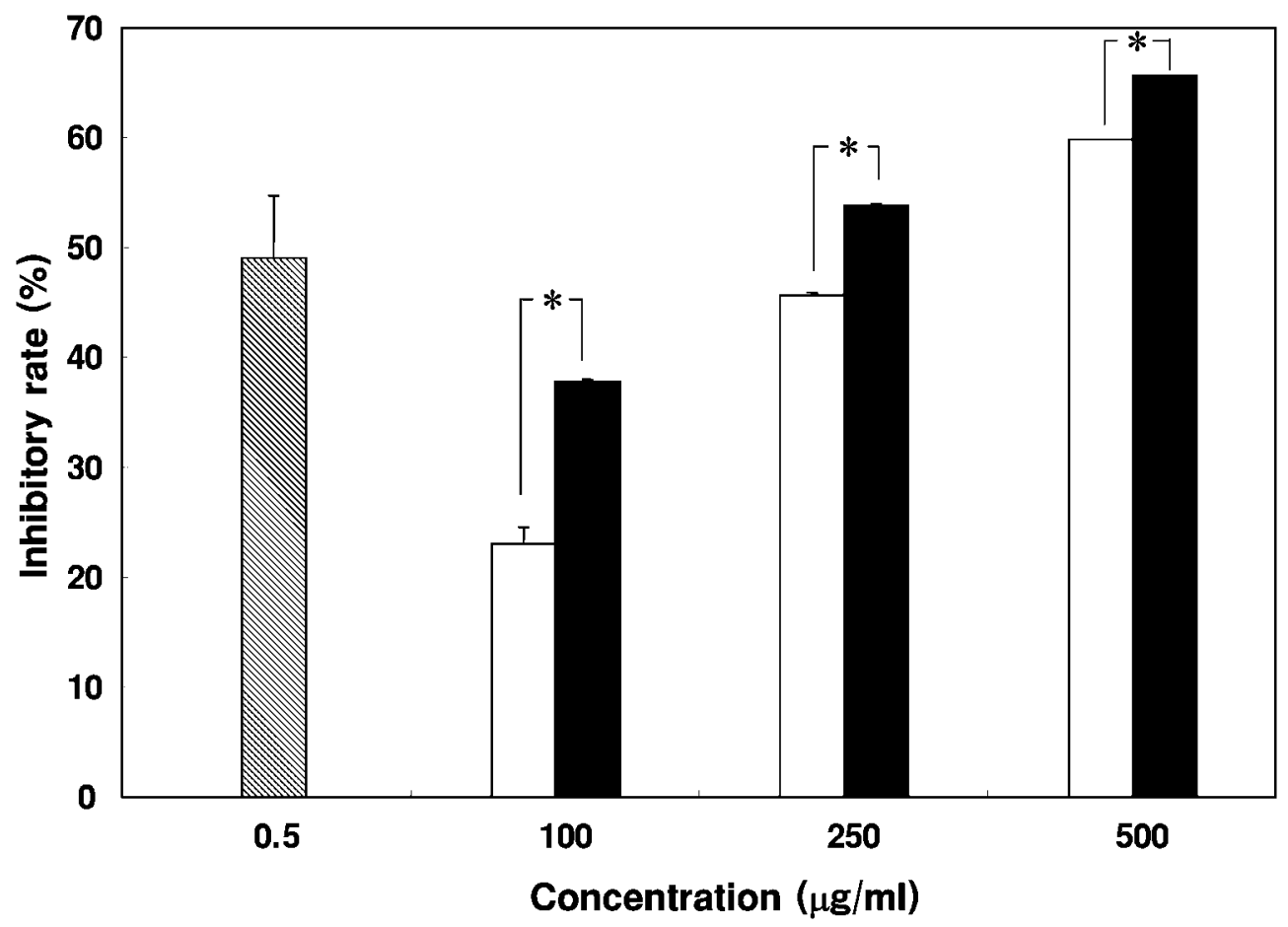

Fig. 1. XOD Inhibitory Activity of Propolis from Brazil and China

Data from 3 times tests are expressed as means \pm S.E. Symbols indicate propolis from Brazil $(\square)$, China $(\square)$ or allopurinol $(\mathbb{\mathbb { N }})$ as positive control. ${ }^{*} p<0.001$, Brazil vs China by Student's $t$-test. 
<smiles>O=c1cc(-c2ccccc2)oc2cc(O)cc(O)c12</smiles><smiles>O=C(O)/C=C/c1ccc(O)cc1</smiles><smiles>CCCCC(C)(C)c1ccc(C=CC(=O)OCCc2ccccc2)c(O)c1O</smiles>

caffeic acid phenetyl ester<smiles>CC(C)=CCc1cc(/C=C/C(=O)O)cc(CC=C(C)C)c1O</smiles>

Fig. 2. Chemical Structure of Five Compounds ( $p$-Coumaric Acid, Artepillin C, Chrysin, Galangin and Caffeic Acid Phenetyl Ester) in Propolis

Table 1. Quantitative Values of Five Compounds

\begin{tabular}{lccccc}
\hline \hline & $p$-Coumaric acid & Artepillin $C$ & Chrysin & Galangin & Caffeic acid phenetyl ester \\
\hline Brazilian & 473 & 2800 & N.D. & 2.3 & 5.3 \\
\hline Chinese & 85 & 170 & 1300 & 607 & 458 \\
\hline
\end{tabular}

N.D.: Not detected, $\mathrm{mg} / 100 \mathrm{~g}$.

Table 2. XOD Inhibitory Activity of Five Compounds

\begin{tabular}{lc}
\hline \hline & $\mathrm{IC}_{50}$ values $(\mu \mathrm{M})$ \\
\hline$p$-Coumaric acid & $>100$ \\
Artepillin C & $>100$ \\
Chrysin & 12.48 \\
Galangin & 14.11 \\
Caffeic acid phenetyl ester & 5.13 \\
Allopurinol & 3.51 \\
\hline
\end{tabular}

るオキソニン酸を投与することにより高尿酸血症モ デル動物を作製し，本動物に対するXOD 活性阻害 作用の強かった中国産プロポリスの血漿尿酸值低下 作用について検討を行つた.

Figure 3 に示したように, 無処置群の血漿尿酸值 は 4 回の採血で平均值で $0.49-0.74 \mathrm{mg} / \mathrm{dl}$ であつ た. 対照群ではオキソニン酸投与前，溶媒投与 1 時 間（オキソニン酸投与 2 時間後），2時間（オキソ 二ン酸投与 3 時間後）及び 3 時間後（オキソニン酸
投与 4 時間後）で血漿尿酸值はそれぞれ $0.47,1.72$, 2.03 及び $2.04 \mathrm{mg} / \mathrm{dl}$ となり，才キソニン酸経口投 与後無処置群に比べ約 3-4 倍に有意に上昇した (それぞれ $p<0.001, p<0.001, p<0.01$, Student's 又 は Welch's $t$-test).

尿酸生成抑制薬であるアロプリノールは，キサン チンの類似物質でありXOD に対して競合的に，代 謝産物であるオキシプリノールは非競合的に作用し て，ヒポキサンチンからキサンチン，キサンチンか ら尿酸のいずれの経路も抑制する現在唯一の XOD 阻害薬4)である。このアロプリノール $10 \mathrm{mg} / \mathrm{kg}$ 投 与群では有意に投与後低值を示し, アロプリノール 投与 2 時間（オキソニン酸投与 3 時間）及び 3 時間 （オキソニン酸投与 4 時間）後に，無処置群と同等 にまで有意に低下した（ $p<0.001$, Dunnet の多重 比較)。一方，尿酸排泄促進薬であるプロベネシド は，近位尿細管での尿酸分泌後の再吸収を抑制する ことにより，尿酸の尿中排泄を促進させる薬剤であ 


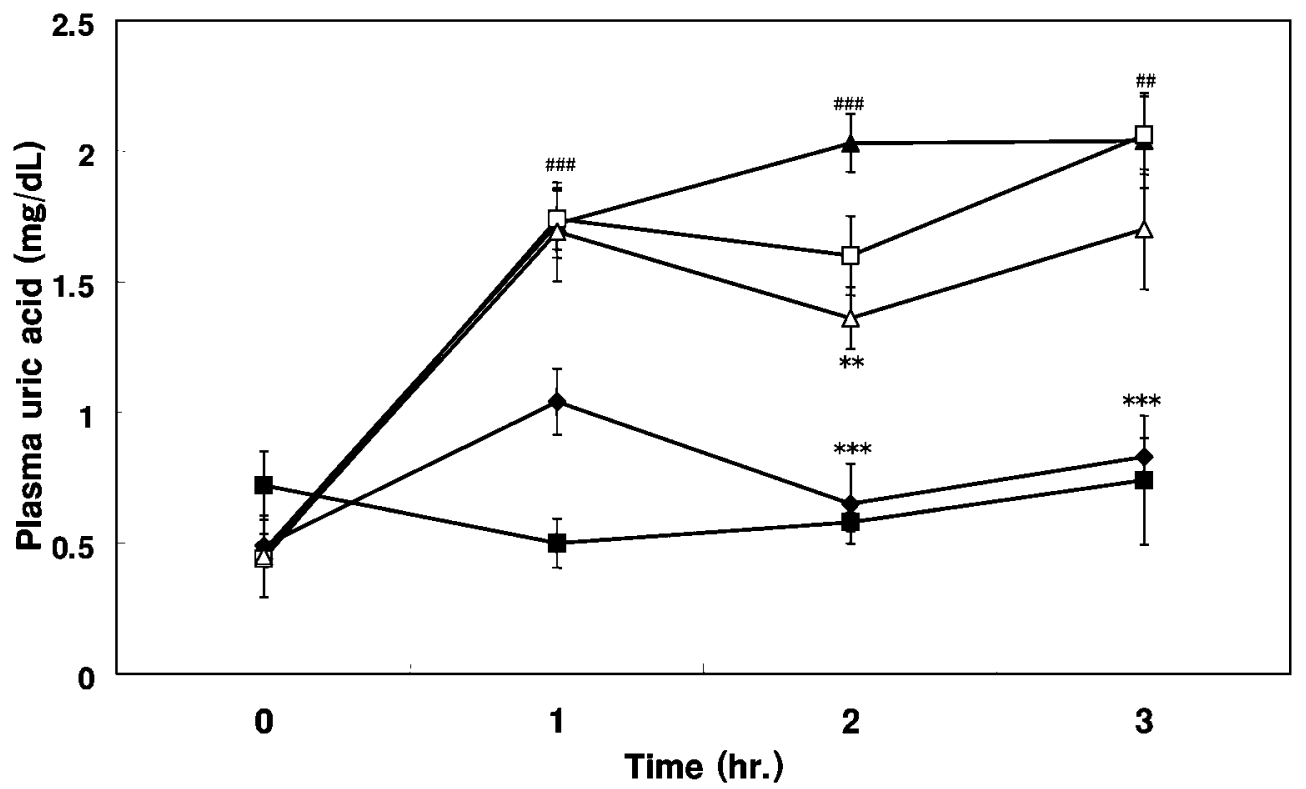

Fig. 3. Effect of Propolis on Plasma Uric Acid Levels in Rats with Oxonic Acid-Induced Hyperuricemia

Data from 5 animals are expressed as means \pm S.E. Symbols indicate non-treatment group $(\boldsymbol{\square})$, control group $(\boldsymbol{\Lambda})$, allopurinol group $(\diamond)$, probenecid group ( $\square$ ) and propolis group $(\triangle) .{ }^{*} p<0.01,{ }^{\sharp \sharp} p<0.001$ vs non-treatment group by Student's or Welch's $t$-test. ${ }^{* *} p<0.01,{ }^{* * *} p<0.001$ vs control group by Dunnett's multiple comparison test.

る. 5) このプロベネシド $100 \mathrm{mg} / \mathrm{kg}$ 投与群では有意 な差は認められなかったものの, プロベネシド投与 2 時間（オキソニン酸投与 3 時間）後で低值を示す 傾向にあった.

これに対し，XOD 活性阻害作用を有するプロポ リス $500 \mathrm{mg} / \mathrm{kg}$ 投与では, 投与後対照群と比較し て低值に推移し，プロポリス投与 2 時間（オキソニ ン酸投与 3 時間）後で $1.33 \mathrm{mg} / \mathrm{dl}$ となり, 対照群 と比較して有意差が認められた $(p<0.01$, Dunnet の多重比較)。また，プロポリス投与 3 時間（オキ ソニン酸投与 4 時間）後では有意な差は認められな かったものの, 低值を示した.

以上のことから，プロポリスの連続的な摂取が, XOD 活性を阻害して尿酸の生成を抑制することに より血漿尿酸值を低下させ, 痛風やそのリスクファ クターである高尿酸血症の予防あるいは治療に有効 であることが示唆された。

今回は, in vitro 試験において XOD 活性阻害作 用の強い傾向を示した中国産プロポリスを用いて in vivo での有効性試験を行ったが，今後は，ブラ ジル産及び中国産プロポリスのオキソニン酸誘発高 尿酸血症ラットにおける血漿尿酸值低下作用の比較 を行い, 尿酸值の低下にはブラジル産プロポリスに 多く含まれている桂皮酸誘導体が重要であるのか,
あるいは中国産プロポリスに多く含まれているフラ ボノイドやカフェー酸フェネチルエステルが重要で あるのかを明らかにする必要があると思われる.

\section{REFERENCES}

1) Terai C., Naika, 85, 375-377 (2000).

2) Fujimori S., Rinshou Eiyou, 97, 709-715 (2000).

3) Hikita M., Gout Nucleic Acid Metab., 24, 139 -151 (2000).

4) Nakajima H., Hyperuricemia Gout, 9, 21-26 (2001).

5) Yamamoto T., Hyperuricemia Gout, 9, 16-20 (2001).

6) Matsuno T., Z. Naturforsch., 50c, 93-97 (1995) .

7) Wang L., Mineshita S., Ga I., Shigematsu T., Matsuno T., Jpn. J. Pharmacol. Ther., 24, 223-224 (1993).

8) Hayashi K., Komura S., Ohishi N., Yagi K., Chem. Pharm. Bull., 47, 1521-1524 (1999) .

9) Tatefuji T., Izumi N., Ohta T., Arai S., Ikeda M., Kurimoto M., Biol. Pharm. Bull., 19, 966 -970 (1996).

10) Amoros M., Lurton E., Bousite J., Girre L., Sauvager F., Cormier M., J. Nat. Prod., 57, 
644-647 (1994).

11) Sugimoto Y., Tarumi T., Kaneko Y., Isayama S., Kawai N., Sugimoto H., Yamada H., Kamei C., Biol. Pharm. Bull., 22, 1237-1239 (1999) .

12) Tazawa S., Warashina T., Noro T., Nat. Med., 54, 306-313 (2000).

13) Kumazawa S., Nakayama T., Honeybeen Sci., 22, 1-8 (2001).

14) Chang W. S., Lee Y. J., Lu F. S., Chiang H. C., Anticancer Res., 13, 2165-2170 (1993).

15) Nagao A., Seki M., Kobayashi H., Biosci. Biotech. Biochem., 63, 1787-1790 (1999).

16) Alberto B., Marina V., Lucia C., Pharmaco. Res. Commun., 17, 831-839 (1985).

17) Chang W. S., Chiang H. C., Anticancer Res., 15, 1969-1974 (1995).

18) Chan W. S., Wen P. C., Chiang H. C., An- ticancer Res., 15, 703-708 (1995).

19) Osada Y., Tsuchimoto M., Fukushima H., Takahashi K., Kondo S., Hasegawa M., Komoriya K., Eur. J. Pharmacol., 241, 183188 (1993).

20) Yonetani Y., Ishii M., Iwaki K., Jpn. J. Pharmacol., 30, 829-840 (1980).

21) Unno T., Sakane I., Kakuda T., Nippon Shokuhin Kagaku Kogaku Kaishi, 47, 740-743 (2000).

22) Koguchi T., Nakajima H., Wada M., Yamamoto Y., Innami S., Maekawa A., Tadokoro T., J. Nutr. Sci. Vitaminol., 48, 184 -193 (2002).

23) Inoki A., Yamaguchi Y., J. Nutr. Food, 4, 103 -112 (2001).

24) Stavric B., Nera E. A., Clin. Toxicol., 13, 4774 (1978). 